\title{
Walter Schmithals \\ en die Johannese Geskrifte
}

\author{
P B Boshoff \\ Universiteit van Pretoria
}

\begin{abstract}
Walter Schmithals and the Johannine literature

The article developed from what was originally intended to be a review of Walter Schmithals's book Johannesevangelium und Johannesbriefe: Forschungsgeshichte und Analyse. Schmithais has since amended some of his earlier views and now presents a historical-critical exegetical summary of the Johannine scriptures. He makes a distiction between the fundamental gospel on the one hand and the gospel and the letters on the other. The prologue and the beloved disciple redaction also receive attention.
\end{abstract}

\section{INLEIDING}

Met 'n lys van publikasies wat in 1952 begin en nog nie afgesluit is nie, sou daar een of ander tyd 'n omvattende werk van Walter Schmithals oor die Johannese geskrifte moes kom. Aan hierdie verwagting het hy voldoen met sy boek. In die newetitel dui die skrywer die twee helftes van sy indeling van die boek aan: Navorsingsgeskiedenis en Analise. 'n Lang inleiding, wat net ses bladsye korter as die kommentaar self is, gaan die eksegese vooraf. In sy oriënterende aanloop kom dit uit dat Schmithals hom in die uitleg van Johannes ingegrawe het en dat hy vroeëre resultate in sy eie beskouing verwerk het. Dat die navorsingsgeskiedenis uitnemend gedoen en aangebied word, staan bo alle twyfel vas. Schmithals verwys nie alleen na boeke nie, maar ook na artikels wat hy geraadpleeg het. Elkeen word by 'n standpunt ingedeel en dikwels word 'n kort en keurige karakterisering daarvan gegee. Hy verwys na 
werke in Engels, Duits, Latyn, Frans, Sweeds, Nederlands en Italiaans sodat dit duidelik is dat hy geen moeite ontsien het om die lesers in die vraagstukke en swarighede van die Corpus Johanneum in te lei nie. En wat meer is, in hierdie boek is jare se werk ingeploeg en dit sal lank neem voordat iemand met soveel gesag weer so 'n onderneming kan voltooi. Schmithals het aanvanklik naam gemaak as Paulusnavorser, later het hy oorspronklike bydraes ten opsigte van die Sinoptiese Evangelies gelewer, en in sy nege en sestigste jaar publiseer hy hierdie deeglike werk oor die Johannesevangelie en Johannesbriewe.

Die waarde van die boek lê sowel in die indeling wat gemaak is, as in die resultate wat bereik is. Die menings, sekerhede en onsekerhede van ander ondersoekers word in die eerste deel genoem en waar nodig bevestig of weerle. Die navorsingsgeskiedenis word nie polemies aangebied nie, maar dit word eerder as die ontwikkeling van dieper insig in die Johannese vraagstukke beskryf. Schmithals se eie kommentaar op die Johannese stof, die tweede deel en swaartepunt van die boek, gee hy rustig en stellend sonder om na ander menings te verwys. So 'n besliste aanbieding maak die resultaat nog meer oortuigend. Aan die begin van sy ontleding gee Schmithals sy siening van die verskillende skrywershande wat aan die Johannese stof gewerk het en die bronne wat tot hulle beskikking was. Hy dui die kriteria aan waarmee elke deel van die materiaal onderskei kan word. Hy slaag daarin om 'n dialogiese element in die teks aan te toon en so by die bekende probleem van die Johannese geskrifte, naamlik dat dit eintlik kontoerloos is, verby te kom. Schmithals onderskei as oudste gedeelte die grondteks van die proloog, daarna volg die teks van die grondevangelie, dié is weer opgeneem in die werk van die evangelis, wat ook die drie briewe van Johannes geskryf het. Uiteindelik is die jongste deel van die Corpus Johanneum aangebring deur die redaksionele werk van die lieflingsdissipelredaksie. Die opnoem van die verskillende dele van die Corpus kan by die leser die indruk van 'n ingewikkelde konstruksie skep. Deur egter in sy behandeling van die stof op die kriteria te konsentreer, slaag Schmithals daarin om die leser as't ware by die ondersoek te betrek. Schmithals het die teks van die proloog en die grondevangelie laat afdruk, nie met die bedoeling om 'n vers vir vers ontleding te gee nie, meer eerder om die tendens daarvan aan te dui en van die verwerking daarvan te onderskei. Die orige materiaal word deur verwysings en die bespreking van die karakter daarvan hanteer. Met so 'n behandeling is dit vir die leser moontlik om in 'n dag of twee Johannes deur te werk.

Die skrywer het 'n omvattende en sluitende verklaring van die Johannese geskrifte gelewer. Solank as wat die histories-kritiese metode nie bevraagteken word nie, maar veral waar dit volhardend toegepas word, sal daar hoë waardering vir hierdie bydrae wees. Die werk wat hiermee vergelyk wil word, sal net so 'n 
omvattende konsep moet aanbied. Onnoukeurighede wat in 'n volgende druk uitgeskakel kan word, kom voor in die inhoudsopgawe waar 'Inhaltsverzeichnis...433' 'Allgemeines Literaturverzeichnis...433' behoort te lees. Op bladsy 176 word 1977 die jaar 'vor Bultmanns Tod' genoem. Dit moet lees 'nach Bultmanns Tod'. 'n Drukfout op bladsy 377 laat 'sehr' in plaas van 'seht' in Johannes 4:29 staan: 'Kommt und seht euch den Menschen an'.

\section{GRONDEVANGELIE EN EVANGELIE}

Getrou aan sy opvatting van die histories-kritiese metode hou Schmithals by die eerste reël van interpretasie deur te vra na die dialogiese situasie. Watter ander mening het die skrywer in die oog, selfs al sou hy dit nie uitdruklik noem nie? Watter ander mening word afgewys? Hoewel hierdie werkwyse nie ernstig bevraagteken word nie en wyd aanvaar word, neem dit uit Schmithals se pen 'n pregnante vorm aan. Dit is ook belangrik om daarop te wys dat Schmithals algaande 'n beter voorstelling van sake verwerf het en in sy jongste publikasie tot 'n aansienlike aanpassing van sy eie vroeëre opvattings gekom het (vgl Schmithals 1984:116-117; 1987:378380). Waar hy aanvanklik met ' $n$ geringe redaksie van die Johannesevangelie rekening gehou het, maak hy nou ' $n$ nuwe verdeling waarby ' $n$ redaksionele verwerking wat ongeveer vyftig persent van die evangeliestof beslaan, na vore kom. Om 'n voorbeeld te noem, die bekende gedeelte van die ware wingerdstok, Johannes 15:117 , lees Schmithals $(1984: 115 ; 1987: 379)$ aanvanklik teen die agtergrond van die stryd tussen sinagoge en kerk. Die gemeente word aangemoedig om nie aan die druk van die sinagoge toe te gee nie, maar in die kerk te bly. In sy nuwe boek stel Schmithals (1992:395) hierdie teks in 'n ander strydsituasie, naamlik dié tussen die ware en valse kerk, die stryd tussen die kerk en die gnostiese dwaalleer. Die ware kerk is die gemeente wat in Christus bly en sodoende ook in die liefde bly en die gebooie onderhou.

Schmithals bevind dat die grondevangelie na aanleiding van die aposunagogos geskryf is. Dit wil sê nadat die tempel in Jerusalem in $70 \mathrm{nC}$ verwoes is, het die Fariseërs ' $n$ Jodedom wat tot in daardie stadium verskillende teologiese opvattings gemoedelik kon akkomodeer, omgebou tot 'n wetsgehoorsame sinagoge. Joodse Christene kon voortaan nie meer binne die sinagogeverband bly nie en buitekant die sinagoge het die kerk geen regstatus gehad nie. In hierdie situasie was daar ' $n$ akute gevaar dat die Christene afvallig kon word. In die omstandighede van die uitdrywing uit die sinagoge, aposunagogos, skryf die grondevangelis die grondevangelie, ongeveer die helfte van die Johannesevangelie, in die laaste dekade van die eerste eeu (Schmithals 1992:158-159, 421). Die grondevangelis skryf sy evangelie om die 
gemeente opnuut aan hulle belydenis te herinner en hulle daarin te bevestig. Tegelykertyd wil hy diegene onder die Jode wat met die kerk simpatiseer, soos Nikodemus, maar wat in die vervolgingsituasie dit nie openlik wil waag om uit die sinagoge te tree en hulle deur die doop by die Christelike gemeente te voeg nie, aanmoedig om die stap te neem (Schmithals 1992:312, 315, 330, 331). Enige werklike leraar van Israel behoort hom te laat doop (Joh 3:10).

So getuig Johannes die Doper teenoor die offisiële afvaardiging van die Jode dat hy nie self die Christus is nie, maar van Jesus sê hy: 'Ek het self ook nie geweet wie $\mathrm{Hy}$ is nie, maar God wat my gestuur het om met water te doop, het vir my gesê: "Die Een op wie jy die Gees sien kom en bly, dit is Hy wat met die Heilige Gees doop". Ek het dit gesien en daarom getuig ek: Hy is die Seun van God' (Joh 1:3334).

By die bruilof in Kana toon Jesus in die Joodse land sy Messiaanse heerlikheid deur 'n wonder: 'En sy dissipels het tot geloof in Hom gekom' (Joh 2:11 - Schmithals 1992:327). Die grondevangelis verander aan die sinoptiese teks oor die genesing van die offisier se slaaf (Luk 7:1-10) en maak van die heidense offisier 'n regeringsbeampte of Herodiaan, 'n Jood dus. Hierdie Jood raak oortuig dat Jesus die Messias is (Joh 4:46b-47, 50-54a - Schmithals 1992:341). Jesus se redevoering met die Samaritaanse vrou ontwikkel so dat Hy self betuig dat Hy die Messias is 'Dit is Ek, Ek wat met jou praat' (Joh 4:26). Vir die Jode se Jesus: 'Julle sal in julle sonde sterwe. Waar Ek heen gaan, kan julle nie kom nie' (Joh 8:21). In sy afskeidsrede verseker Jesus egter diegene wat in Hom glo, dat hy heen gaan om vir hulle plek te maak en dat Hy weer sal kom om hulle saam te neem (Joh 14:3). Daarby word nog 'n 'Ek-is'-formule gevoeg om veral die sinagoge as 'n buite-Christelike moontlikheid tot heil uit te sluit: 'Ek is die weg en die waarheid en die lewe. Niemand kom na die Vader toe behalwe deur My nie' (Joh 14:6 - Schmithals 1992:389-390). Selfs in die lydensgeskiedenis werk die grondevangelis nie met 'n theologia crucis nie, maar is dit die Jode wat Hom by Pilatus aangee omdat Hy daarop aanspraak maak dat Hy die Seun van God is. Jesus tree ook daar soos die verwagte Messias op deurdat Hy soewerein oor sy lewenslot beskik (Schmithals 1992:404-405). In die laaste toneel wat die grondevangelis skilder, is dit die gemeente wat deur Jode bedreig word, maar tog die vreugde het dat hulle verhoogde Here by hulle is: 'Daardie Sondagaand was die dissipels bymekaar. Alhoewel die deure gesluit was omdat hulle bang was vir die Jode, het Jesus gekom en tussen hulle gaan staan en vir hulle gesê: "Vrede vir julle!"' (Joh 20:19 - Schmithals 1992:411-412).

Schmithals (1992:219) kom tot die gevolgtrekking dat die bewerker van die grondevangelie, die evangelis, van die skryfwerk van die grondevangelis gebruik gemaak het in sy stryd teen die dosetisme. Dit is ook sy hand wat die briewe van 
Johannes geskryf het. Hy sluit aan by die taal van die grondevangelie. Waar die grondevangelis uitgaan van die tema: Jesus is die Christus, kon die bewerker hierdie stelling oorneem en dit net anders beklemtoon: Jesus is die Christus, om dit in belang van sy stryd aan te wend. Schmithals (1992:293-294) kon afsien van 'n noukeurige grammatikale en linguïstiese analise van die Johannese taal omdat die literêre en inhoudelike gegewens voldoende grond verskaf om sy verklaring deur te voer.

Schmithals (1992:287-288) identifiseer die evangelis as die presbutor of oudste soos hy homself duidelik as die afsender van 2 en 3 Johannes noem. Hy is die skrywer van die Johannesbriewe en van die helfte van die Johannesevangelie wat hy as 'n eenheid uitgegee het. Die presbutors was in die Christelike tradisielyn die volgende skakels na die oog-en oorgetuies en kon hulleself, synde leerlinge van die apostels, aanbeveel as betroubare draers en deurgewers van die eg-Christelike leer. Hulle was nie skakels in 'n opeenvolging van die amp nie, maar skakels in die regte oordrag van die leer. Die lesers kon onder die indruk kom dat eerstehandse ooggetuies aan die woord is: 'Ons het Hom self gehoor; ons het Hom met ons eie oë gesien; ja, ons het Hom gesien en met ons hande aan Hom geraak' (1 Joh 1:1). Dit hoef egter nie deur ooggetuies geskryf te gewees het nie, want die ooggetuieskap word in die geloofsgemeenskap, waar almal gelykwaardige getuies is en die verlede teenswoordige werklikheid word, opgehef. Hierdie saak word duidelik wanneer gelet word op 1 Johannes 4:12: 'Niemand het God nog ooit gesien nie, maar as ons mekaar liefhet, bly God in ons en het sy liefde in ons sy doel volkome bereik'. Ook in Johannes 19:35 onderskei die evangelis hom van die ooggetuie wat die spiessteek en die vloei van water en bloed gesien het: 'Hy wat dit gesien het, lê daarvan getuienis af, en sy getuienis is waar'. Schmithals oorweeg dit dat die evangelis oortuig kon wees dat die grondevangelie ook deur een van die ouderlinge geskryf is.

In verband met die getuienis van Johannes die Doper waar Johannes volgens die grondevangelie die funksie het om vas te stel dat die Gees op Jesus as die verwagte Messias kom, bewerk die evangelis dit so dat die inhoud van die doopgebeure Jesus se menswording is. Schmithals (1992:322) stel dat die evangelis se weergawe van wat by Jesus se doop gebeur het, in samehang met 1 Johannes 5:1-13 verklaar moet word. In 1 Johannes 5:6 word 'n antidualistiese standpunt ingeneem dat die 'Een wat deur die water van sy doop en die bloed van sy dood na ons toe gekom het', Jesus Christus is. Die grondevangelis laat Johannes vir Jesus anders sien as wat die evangelis dit doen. Die grondevangelie stel: 'Die Een op wie jy die Gees sien kom en bly, dit is Hy wat met die Heilige Gees doop. Ek het dit self gesien en daarom getuig ek: Hy is die Seun van God' (Joh 1:33-34). So sien Johannes van die evangelis nie vir Jesus nie, maar meer direk, historiserend: 'Die volgende dag sien 
Johannes vir Jesus na hom toe kom' (Joh 1:29). 'n Verdere aanduiding dat die evangelis Jesus se doop as 'n getuienis vir sy menswording wil gebruik, is dat hy Johannes pertinent na 'n man laat verwys: 'Ná my kom daar 'n man wat my vór is, want Hy was voor my reeds daar' (Joh 1:30). Aan hierdie man knoop die evangelis sy sentrale motiewe vas: 'Dáár is die Lam van God wat die sonde van die wêreld wegneem' (Joh 1:29). As Lam sterf Christus antidoseties vir die sonde van die wêreld. Volgens Schmithals (1992:306) gee die evangelis onder andere hiermee uitdrukking aan sy theologia crucis en toon dat hy vertroud is met begrippe en formules uit die Hellenistiese Joodse Christendom. Hierdie Antiogeense soteriologie het uitdrukkings soos 'oorgegee', vir ons', versoening' gebruik.

Schmithals (1992:429) meen dat die grondevangelis die soteriologiese model van vernedering en verhoging van die Seun van God volg. 'n Model wat nog ouer as die kruisteologie kan wees. Hy maak verder gebruik van die sending-Christologie en die pre-eksistente-Christologie. Dat Jesus deur die Vader gestuur is, wil beklemtoon dat Hy die Messias is (Schmithals 1992:296, 427, 430). Die evangelis sluit hierby aan en voer aan dat Jesus liggaamlik uit die hemel gekom het: 'Jesus het geweet dat die Vader alles in sy hande gegee het en dat Hy van God gekom het en na God teruggaan' (Joh 13:3 - Schmithals 1992:298). Schmithals (1992:282) vind 'n verwysing na die pre-eksistensie van Jesus in die vers: 'Ek skrywe vir julle, vaders, omdat julle Jesus ken wat van die begin af daar was (1 Joh 2:13; vgl 1 Joh 1:1).

Vir sy stryd teen die dosetisme verbind die evangelis Jesus met die Joodse feeskalender. Jesus neem deel aan drie paasfeeste, 'n loofhuttefees en tempelwydingsfees. Behalwe vir sy deelname aan feeste, reis Jesus ook meer as in die grondevangelie. Die motief daarvoor is om Jesus in sy omgewing nog sterker as ware mens te teken. Vir hierdie doel het die evangelis verstellings aan die grondevangelie aangebring om Jesus minstens vier maal na Jerusalem te laat reis, in plaas van die een reis wat die grondevangelis en die Sinoptiese Evangelies beskryf (Schmithals 1992:300301, 417-420). Die evangelis verander ook Jesus se doodsdatum om by sy boodskap te pas. Waar die Sinoptiese Evangelies Jesus die Donderdag 'n paasmaaltyd laat eet, laat die evangelis die maaltyd wegval om Jesus te laat sterf op die tydstip waarop die paaslam geslag moet word: $\mathrm{Hy}$ is die liggaamlike paaslam wat ' $\mathrm{n}$ werklike dood sterf (Schmithais 1992:306, 382, 407). Jesus sterf tot vergifnis van sondes (Schmithals 1992:306) om die dwaalleraars te weerlê wat ontken dat daar sonde en sondevergifnis is (Schmithals 1992:413). Hy word liggaamlik opgewek en sy terugkeer tot die Vader is ook liggaamlik (Schmithals 1992:299, 412-413).

Die sogenaamde hoë Christologie skryf Schmithals (1992:296, 344, vgl 298) aan die grondevangelis toe. By hom is daar 'n eenheid tussen die Vader en die Seun. Die eenheid is dinamies, dit wil sê God handel in Christus. Hy is Seun van God. 
Die sogenaamde lae of subordinasiaanse Christologie vind Schmithals (1992:296, 384-385) by die evangelis. Hiervolgens maak die Vader die Seun wat $\mathrm{Hy}$ is, $\mathrm{Hy}$ is dit nie vanself nie. Die menseseun word deur die Vader verheerlik. Hy is ook deur God gestuur, as liggaamlike is Hy gestuur (Schmithals 1992:297). Daar is nie so iets soos 'n pneumatiese opstyg na die hemel toe nie. Die enigste kennis van die hemelse word deur die aardse mens Jesus gebring: 'Niemand op die aarde was al in die hemel nie behalwe Hy wat uit die hemel gekom het, naamlik die Seun van die mens' (Joh 3:13 - Schmithals 1992:332). Schmithals (1992:297, 429) kom tot die gevolgtrekking dat Bultmann se opvatting van die genoegsaamheid van die 'Dat Jesus gekom het' tot 'n mate reg aan die teologie van die evangelis laat geskied, maar nie in die geval van die grondevangelis nie.

Die gnostiese dwaalleraars het gemeen dat hulle vry van sonde was (Schmithals 1992:282-283). Vir die pneuma wat in die vreemde wêreld gevange is, is daar nie sonde nie, want die pneuma is essensieel goddelik. As die gnostici sê dat hulle 'gemeenskap met God' het (Joh 1:6), bedoel hulle daarmee dat die pneuma met God identies is. Uit die oogpunt van die siel van die pneumatikus wat na die hemel toe opvaar en wegkom van die liggaamlike wêreld, kan hulle verklaar: 'Ons het geen sonde nie' ( 1 Joh 1:8, 10). Teenoor en teen die dualistiese opvatting van 'n goddelike en antigoddelike sfeer verklaar die evangelis dat die mens nie nodig het om soos God te wees nie, hy mag sondaar wees. Sy sonde word vergewe. Van die vergeefde sondes onderskei die evangelis die doodsonde (1 Joh 5:16) wat bestaan in die saamgaan met die afvalligheid van die dwaalleraars. Hiervoor word nie om vergewing gebid nie, dit moet dadelik gestaak word. Geen verbintenis moet met die dwaalleraars onderhou word nie, hulle word nie in die huise ontvang nie en nie gegroet nie (2 Joh 10). In kontras hiermee word Gaius geloof vir die gasvryheid wat hy bewys het aan diegene wat ter wille van die Naam Jesus op reis was, bewys het ( 3 Joh 5-8 - Schmithals 1992:289).

Schmithals (1992:283-284) lees in die voortdurende vermaning tot broederliefde, byvoorbeeld 2 Johannes 5: 'Ons moet mekaar liefhê', nie 'n oproep tot 'n spesifieke sosiale gedrag vir die gemeente nie. In die lig van die polemiese teksverband dui dit eerder op 'n vermaning om getrou aan die gemeente en die oorgelewerde Christelike tradisie te bly en nie liefdeloos van die gemeente weg te breek nie.

Oor die dualistiese uitdrukkingswyse van die grondevangelis dat ' $(w)$ at uit die vlees gebore is, is vlees, en wat uit die Gees gebore is, is Gees' (Joh 3:6) het die evangelis gevoel dat dit water op die meule van die dosete is met wie hy in 'n stryd gewikkel is. Vir die dosete was die Gees hooftema van hulle teologie en daarom moet die evangelis ook 'n leer van die Gees ontwikkel. So korrigeer hy die dualistiese taalgebruik met die opmerking: 'Die wind waai waar hy wil. Jy hoor sy geluid, 
maar weet nie waar hy vandaan kom en waar hy heen gaan nie. So gebeur dit met elkeen wat uit die Gees gebore is' (Joh 3:8). Die dwaalleraars het geleer dat die Gees iets is wat 'n mens self saambring, dit is sy eie bydrae. Die evangelie stel daarteenoor dat die Gees gawe van God is, die Gees waai waar Hy wil, dit wil sê dit word nie die besit van die pneumatikus nie. Hy word gegee en ontvang (Schmithals 1992:281, 310-311, 393). Gees is die aanduiding en erkenning dat Jesus werklik mens was. 'Strome lewende water', dit wil sê die Gees vloei uit Jesus se 'binneste', dit is uit sy liggaam (Joh 7:38-39 - Schmithals 1992:363). Van Jesus se verhoogde liggaam kom die Gees. Daarom ontvang net die gelowiges en nie die dosetiese dwaalleraars nie, die Gees. Ná sy verhoging kan Jesus nie meer liggaamlik by sy gemeente teenwoordig wees nie en in sy plek werk die Heilige Gees. Hierdie teologiese ontwerp kon die evangelis van Lukas oorgeneem het (Schmithals 1992:311). Teenoor die pneumatici se sug om van die wêreld verlos te word, word die Gees na die gemeente gestuur om vir altyd by hulle te wees: 'Ek sal die Vader vra, en Hy sal vir julle 'n ander Voorspraak stuur om vir ewig by julle te wees, naamlik die Gees van die waarheid' (Joh 14:16-17 - Schmithals 1992:393). Die Gees is maar net trooster, nie die verlengde van die goddelikheid wat die pneumatici uit hulleself laat opskiet nie. Die Gees word 'in my Naam' (Joh 14:26) gestuur. Die gebed in Jesus se Naam is die gebed om die Heilige Gees. Schmithals $(1992: 301,393)$ verduidelik dat dit net na die eienaam van die mens Jesus kan verwys. In hierdie Naam bid die ware gemeente (Joh 14:14) en ontvang vergewing van sondes (1 Joh 2:12).

In verband met die bekende probleem van die volgorde van die teks van die Johannesevangelie, skryf Schmithals $(1992: 300-301 ; 414)$ die verplasings van perikope in die evangelie soos die grondevangelis dit gehad het, aan die hand van die evangelis toe. Die rede waarom hy dit gedoen het, was om van die een besoek aan Jerusalem meer besoeke te maak. Vir die grondevangelis het Nikodemus byvoorbeeld, wat in Jerusalem hoort, eers later, by die enigste verblyf in Jerusalem, in die verhaal voorgekom. Die evangelis skuif hom vorentoe om deel uit te maak van die eerste Jerusalembesoek. Wie, soos Jesus, gereeld in Jerusalem kon kom en sy feeste vier, maak deel uit van die land en volk onder wie hy woon - 'n motief wat die evangelis inspan om duidelik te maak dat die Seun van God werklik grond gevat het en nie in 'n skyngedaante liggies oor die aarde gesweef het nie.

Schmithals (vgl 1992:148-149) het gaandeweg 'n voorstelling van die oer-Christendom opgebou waarvolgens die Palestynse Joodse Christendom (Judaïsties) tegelykertyd in twee rigtings verder ontwikkel, naamlik die Hellenistiese Joodse Christendom of Hellenisties sinogogale Christendom (Hellenisties) en die suiwer universalistiese Christendom (gnosties). Die voorloper van die universalistiese Christendom was 'n entoesiasties-dualistiese rigting wat op Palestynse bodem in die Jode- 
dom ontstaan het. Die Christendom het met hierdie Joodse gnostiek missionêr in aanraking gekom en die resultaat van die aanraking was dat die Christelike teologie die universalisme en samehangende wetsvrybeid oorgeneem het, maar nie die dualisme van die gnostiese sisteem nie. Die substansiële dualisme is in 'n beslissingsdualisme omgesit. Stefanus moes in hierdie ontwikkeling 'n beduidende rol gespeel het. Hierdie ontwikkeling verteenwoordig die teologiese rigting waarbinne Paulus tot bekering gekom het. Die Johannese teologie, dit wil sê dié van die gronóevangelis en die evangelis, wortel in die universele Christendom.

\section{DIE PROIOOG}

Wat die proloog. Johannes 1:1-18, betref, gee Schmithals (1992:270-271) sy eie afbakening van die lied wat ten grondslag van hierdie verse lê. Daar is al baie voorstelle oor die afmerk van so 'n gedig gemaak en Schmithals het self vroeër (1979) 'n ander indeling gemaak. Die eerste strofe van die 'Vorlage' vind hy in verse 1, 2 en 3, die tweede in verse 4, 5 en $12 \mathrm{a}$ en $\mathrm{b}$. Elkeen van hierdie strofes bestaan uit vyf en dertig Griekse woorde. Die derde strofe bestaan uit verse 14a, b, c, e en 17a, b. In 1979 het Schmithals (1979:32) vers 14d ['die heerlikheid wat Hy, as die enigste Seun, van die Vader het'] ook deel van die himne gemaak om 'n strofe bestaande uit veertig Griekse woorde te kry, nadat hy twee woorde 'die Woord' by vers $14 \mathrm{~b}$ gevoeg het. Sy nuwe indeling kort nog twee woorde om vyf en dertig te maak en in plaas van die 'die Woord' in vers $14 \mathrm{~b}$ stel hy 'en Hy was' in vers $14 \mathrm{e}$ voor. Wat opvallend is, is dat Schmithals in 1979 so seker van sy getalle was. Dat daar vyf en dertig woorde in elk van die eerste twee deelstrofes is, moes 'n mens laat dink dat daar veertig in die tweede gaan wees. Die eerste strofe het altesaam twaalf reëls en die tweede sewe. In die nuwe indeling kry die tweede strofe ook net vyf en dertig woorde soos die deelstrofes. Hierdie keer argumenteer Schmithals dat as daar vyf en dertig woorde in die deelstrofes is, moet 'n mens verwag dat daar ook vyf en dertig in die tweede strofe sal wees. Wat egter nie genoem is nie, is die dieperliggende insig op grond waarvan Schmithals hierdie verandering maak. Vers $14 \mathrm{~d}$ maak volgens Schmithals (1992:275) eerder deel van die himniese onderbou uit van die redaksionele bewerking van die grondevangelis. Saam met vers 18 'Niemand het God ooit gesien nie. Sy eniggebore Seun, self God, wat die naaste aan die Vader is, dié het Hom bekend gemaak' radikaliseer vers $14 \mathrm{~d}$ die Christelike openbaringsvoorstelling teenoor die voorstelling van die tweede strofe, waarvolgens die 'kinders van God' (Joh 1:12) nie op Christene of selfs die Ou-Testamentiese vromes dui nie, maar op voor-Christelike vromes wat die reg ontvang het om 'kinders van God te word'. Die grondevangelis wil ook met vers 14d dit aan die Jode duidelik maak dat Jesus die Messias, die 
eniggebore Seun van God is; sonder Hom is daar niemand wat God ken nie (Schmithals 1992:296). Die grondevangelis bring ook vir Johannes die Doper in om reeds die eerste strofe op Christus te betrek en teenoor die Jode te getuig dat die sinagoge nie reg optree deur Christus te verwerp nie.

Schmithals (1992:272) meen dat die wysheidsmite die grondslag vorm waarop die proloog gebou is. Tog deel hy nie die sienswyse dat ons hier met 'n voor-Christelike lied te doen het nie. Vanuit die staanspoor is die gedig afgestem op die triomfantelike slot: 'Die genade en waarheid het deur Jesus Christus gekom'. In die eerste twee strofes gaan die proloog van 'n algemene openbaring uit wat egter nie aangeneem word nie. Die lig word nie deur die duisternis aanvaar nie. Die universalisme word in vers 17 op die spits gedryf waar 'genade en waarheid' teenoor die wet' gestel word. Die teenstelling in vers 17 word nog radikaler deurgevoer as wat Paulus dit doen in sy teenstelling van 'Geregtigheid uit die wet - geregtigheid uit die geloof. Paulus kan die wet nog in diens van die genade stel, hier kry die wet geen positiewe funksie om te vervul nie. Schmithals (1992:149, 273-274) lokaliseer die outeur van die proloog in dieselfde oorsprongsgebied van waar Paulus en 'Johannes', dit wil sê die grondevangelis en die evangelis, hulle universalistiese, wetvrye Christendom geleer het. Die teologiese hoofgedagtes van die proloog, naamlik die pre-eksistente-Christologie, vleeswording, teologie van die Woord en die eskatologiese bewussyn van die gemeente, wys ook in hierdie rigting.

\section{DIE LIEFLINGSDISSIPEI REDAKSIE}

Schmithals aanvaar dat die figuur van die lieflingsdissipel nie deel van die grondevangelie of evangelie is nie, maar eers in die laaste redigering van die Johannese geskrifte bygevoeg is. Hy noem hierdie redaksie ook die lieflingdissipelredaksie. Die redaksionele toevoeging bestaan uit Johannes 6:63; 13:20-26a, 36-38; 16:12-13; 18:15-18, 24-27; 19:24b-27; 20:2-11a; 21:1-25 (Schmithals 1992:258).

Dat Jesus hierdie dissipel liefgehad het (bo Joh 13:23), is 'n emosielose aanduiding daarvan dat hy waardig geag is om te geld as 'n outentieke apostoliese getuie (Schmithals 1992:231). Petrus het dieselfde status geniet en miskien het hy deur sy martelaarskap hom bo die ander verhef, 'meer as hulle hier', sodat hy die eerste plek in die rangorde van getuies beklee het:

Toe hulle klaar geëet het, vra Jesus vir Simon Petrus: 'Simon seun van Johannes, het jy my lief, meer as hulle hier?' 'Ja Here', antwoord hy Hom, 'U weet dat ek U liefhet'. Hy sé toe vir hom: 'Laat my lammers wei'. Jesus vra hom weer 'n tweede keer: 'Simon seun van Johannes, 
het jy my lief?' 'Ja Here', antwoord hy Hom, 'U weet dat ek U liefhet'. Hy sê toe vir hom: 'pas my skape op'. Jesus vra hom die derde keer: 'Simon seun van Johannes, het jy my lief?' Petrus het bedroef geword omdat Jesus hom die derde keer gevra het: 'Het jy my lief?' En hy antwoord Hom: 'Here $U$ weet alles. U weet dat ek $U$ liefhet'. Hy sê toe vir hom: 'Laat my skape wei'.

(Joh 21:15-17)

Die bedoeling van hierdie gedeelte is om Petrus en die lieflingdissipel te paralleliseer. Jesus het die lieflingsdissipel lief en Petrus het Jesus lief. Deur die liefde word dieselfue verhouding tussen die Here en sy twee dissipels beskryf (Schmithals 1992:231).

Om die historiese omstandighede van hierdie gegewens nader te bepaal, wys Schmithals (1992:239) daarop dat die drievoudige opdrag aan Petrus: 'Laat my lammers wei', 'Pas my skape op', 'Laat my skape wei' reeds die primaataanspraak van die gemeente in Rome veronderstel. Die herder wat die skape laat wei, is beeld van die gemeenteleier. Hierdie beeld van Petrus as die groot kerkleier pas egter nie by hom gedurende sy eie leeftyd nie. Eers ná sy martelaarskap in Rome en in verband met die primaataanspraak van die kerk in Rome het Petrus se gestalte so toegeneem dat hy as die leier van die kerk as geheel geteken is. Sy martelaarskap was die begronding van Petrus se ampgesag en die beseëling van sy outoriteit as die outoriteit van die gemeente in Rome en van die biskop daar. Die tekste waarin die lieflingsdissipel optree om met Petrus geparalleliseer te word, moet dus gedateer word in 'n tyd toe die primaataanspraak van Rome al gemaak is (Schmithals 1992:239).

Schmithals (1992:241) kom tot die konklusie dat die bedoeling van die lieflingsdissipelredaksie was om erkenning van die gemeente in Rome te verkry vir die Johannesevangelie op grond daarvan dat die skrywer van die evangelie, die lieflingsdissipel, gelykwaardig aan Petrus in apostoliese gesag was.

Om te bepaal wie die lieflingsdissipelredaksie gebruik om die Johannesevangelie deur die kerklike gesag van Rome goedgekeur te kry, ontleed Schmithals Johannes 21:20-23:

Toe Petrus omdraai, sien hy die dissipel volg vir wie Jesus lief was, wat ook by die maaltyd op sy bors geval en gesè het: 'Here, wie is dit wat U gaan oorlewer?' Toe Petrus hom sien, vra hy vir Jesus: 'Here, wat van hom?' Jesus antwoord hom: 'As Ek wil hê dat hy bly totdat Ek kom, wat gaan dit jou aan? Volg jy my'. Hierdie woord het toe onder die broers uitgegaan dat daardie dissipel nie sou sterwe nie. Jesus het egter nie vir hom gese dat hy nie sou sterwe nie, maar: 'As Ek wil hê dat hy bly totdat Ek kom, wat gaan dit jou aan?' Dit is daar- 
die dissipel wat van hierdie dinge getuig en hierdie dinge geskryf het, en ons weet dat sy getuienis waar is.

Schmithals (1992:248) voeg hom by die aanname dat die dissipel wat sou bly lewe totdat Jesus kom, ook die skrywer van Openbaring moet wees. Meer as een keer sê Jesus in Openbaring 'Ek kom gou' (bv Openb 3:11) en die afleiding sou gemaak kon word dat hierdie leraar nie sou sterf voordat die Here kom nie. Die teenstanders van Openbaring het die mistasting van die skrywer daarvan uitgebuit om die boek in onguns te bring. Hierdie beskuldiging word beantwoord met die verduideliking dat Jesus nie gesê het dat hy nie sou sterwe nie. Dit is 'n misverstand. Jesus het bloot 'n veronderstelling genoem, naamlik dat as Hy wou hê dat Johannes moes bly tot die wederkoms, raak dit nie Petrus se lewensloop nie (Schmithals 1992:248, 253). Hierdie verduideliking het volgens Schmithals die aansien van die Openbaring van Johannes en die apostoliese gesag van sy skrywer gered, en tegelyk onthul dat die lieflingsdissipel volgens die tradisie identies aan hierdie Johannes, seun van Sebedeus, is. Voor die redaksionele bewerking van die Johannesevangelie, is dit beskou as die geskrif van 'n onbekende skrywer. Deur die redaksie word dit nou aan die apostel Johannes toegeskryf, wat reeds lankal beskou is as die skrywer van Openbaring.

Schmithals (1992:252) historiseer sy argument verder met die opmerking dat die Montaniste in die tyd toe die kanon gevorm is, 160 - 180, hulle in Frigië, waar hulle bedrywig was, op die uiteenlopende geskrifte van die Johannesevangelie en Openbaring beroep het. Hulle het onder druk van vervolgings van staatsweë die Openbaring van Johannes lewendig gehou en die koms van die nuwe Jerusalem en die duisendjarige ryk in die nabye toekoms in Pepuza verwag. Dat hierdie profetiese aanspraak van hulle gegrond is, het hulle nie aan getwyfel nie, want die parakleet is aan hulle belowe: 'Ek sal die Vader vra, en Hy sal vir julle 'n ander Voorspraak stuur om vir ewig by julle te wees, naamlik die Gees van die waarheid. Die wêreld kan Hom nie ontvang nie, omdat hulle Hom nie sien nie en Hom nie ken nie. Maar julle ken Hom, omdat Hy by julle bly en in julle sal wees (Joh 14:16-17).' Montanus het homself buitendien as die parakleet beskou, sodat daar by die Montaniste 'n verwantskap met die Johannesevangelie bestaan het.

Schmithals (1992:253) is oortuig dat Montanus en sy apokaliptiese beweging die eerstes was wat hulle op Openbaring en die parakleet van die Johannesevangelie beroep het en daarom herlei hy die redigering van die Johannesevangelie deur die lieflingsdissipelredaksie terug na die vroeë Montaniste. Die redaksie is onderneem om enersyds die apostolisiteit van Openbaring te handhaaf en daarmee saam ook die apokaliptiese verwagting van die Montaniste. Andersyds voorsien die redaksie die Evangelie en die ingeslote parakleetbeloftes van apostoliese status, om sodoen- 
de die Montanistiese profesie te regverdig. Dit het gebeur met die uitdruklike erkenning en eerbiediging van die gesag van die Roomse gemeente en in direkte of indirekte verband met die vorming van die kanon.

Vermoedelik was die aanknopingspunt tussen die Johannesevangelie en die Montaniste die belofte van die Heilige Gees wat in die evangelie gemaak word. Die Montaniste het daarby aangesluit en dit vir hulleself aangepas. Schmithals (1992: 256) twyfel nie daaraan dat die Montanistiese hand by die laaste van die parakleetgedeeltes ingegryp het nie: 'Ek het nog baie dinge om vir julle te sê, maar julle sal dit nou nie begryp nie. Wanneer Hy kom, die Gees van die waarheid, sal Hy julle in die hele waarheid lei. Wat Hy sal sê, sal nie van Homself kom nie: Hy sal net sê wat Hy hoor, en Hy sal die dinge wat gaan kom, aan julle verkondig' (Joh 16:12-13).

Hierdie opmerking staan in direkte teenstelling tot Johannes 15:15 waar Jesus verseker dat Hy 'alles' bekend gemaak het. Hier word egter gesê dat eers die Gees hulle in die waarheid sal lei. Dit staan ook in kontras met Johannes 14:26 waar die Gees die funksie kry om hulle te leer, dit wil sê om hulle te herinner aan alles wat Jesus gesè het. Dit is tipies van Montanus en sy profesie om die nog verborge gebeure te onthul (Schmithals 1992:257).

\section{SLOTOPMERKINGS}

Wat opvallend is, is dat Schmithals (1992:164; vgl 1967:152) nog steeds waardering uitspreek vir die nut wat Bultmann se kommentaar op die Johannesevangelie vir die preekmaker het. Dit is nog te meer merkwaardig indien 'n mens in ag neem dat Bultmann glad nie in dieselfde mate as Schmithals aandag aan die historiese kritiek gegee het nie of ten minste nie daarin kon slaag om die Johannese geskrifte met soveel vertroue in die geskiedenis terug te verplaas soos laasgenoemde nie. Bultmann bied bewustelik 'n teologiese uitleg van die Evangelie aan (Schmithals 1992: 165), iets wat Schmithals nie met Johannes probeer nie, maar wel met Markus (Schmithals 1979a) op onoortreflike wyse gedoen het. Dat Schmithals (1992:432) die leser na Bultmann se kommentaar, ook in die laaste sin van sy boek, verwys, moet uit sy beskouing verklaar word, naamlik dat daar 'n onuitgesproke Christelike dogmatiek in die agtergrond van die kanonieke geskrifte lê en deur die prediker in die uitleg ingebring moet word as hy verantwoordelik met die tekste wil omgaan. Veral waar Bultmann sy teologiese eksegese wen uit 'n bewerking wat die evangelis van gnostiese redevoeringe maak, dui hy die weg aan wat die eksegese moet gaan. Die bekende teks: 'In die wêreld sal julle verdrukking hê; maar hou goeie moed, Ek het die wêreld oorwin', lei Schmithals daartoe om wêreld hier nie eenvoudig as ruimte, plek te verstaan nie. Dit is eerder die aanduiding van 'n mag wat die mens 
aan die skepping toeken as hy dit tot die oorsprong en grond van sy lewe maak (Schmithals 1992:309-310, 401). So 'n uitleg het van Bultmann af al bekend geword (bv Bultmann 1968:33-34). Die dwaalleraars, en hulle Joodse verteenwoordigers, is aan hierdie mag verval, terwyl die gemeente daarvan bevry word - dít is die historiese toespitsing wat Schmithals aan hierdie stuk dogmatiek gee. Of liewer omgekeerd: Die onderskeid wat daar tussen die gemeente en die dwaalleraars bestaan, veroorloof die eksegeet om aan 'wêreld' so 'n betekenis te heg.

\section{BIBLIOGRAFIE}

Bultmann, R [1941] 1968. Das Evangeluim des Johannes. Göttingen: Vandenhoeck (KEK.)

Schmithals, W [1966] 1967. Die Theologie Rudolf Bultmanns: Eine Einführung. 2.Aufl. Tübingen: Mohr.

--- 1979. Der Prolog des Johannesevangeliums. ZNW 70, 16-43.

-.- 1979a. Das Evangelium nach Markus, 2 Bde. Gütersloh: Mohn. (ÖTK 2/1; 2/2; GTB-Siebenstern 502; 503.)

--- 1984. Neues Testament und Gnosis. Darmstadt: Wissenschaftliche Buchgesellschaft. (Erträge der Forschung 208.)

-- 1987. Der Konflikt zwischen Kirche und Synagoge in neutestamentlicher Zeit, in Oeming, M \& Graupner, A (Hrsg), Altes Testament und christliche Verkündigung: Festschrift für Antonius $H J$ Gunneweg zum 65 Geburtstag, 366-386. Stuttgart: Kohlhammer.

-.- 1992. Johannesevangelium und Johannesbriefe: Forschungsgeschichte und Anabyse. Berlin: De Gruyter. (BZNW 64.) 